Article

\title{
Nuclear Deficit: Why Nuclear Weapons Are Natural, but Scotland Doesn't Need Nature
}

\author{
Michael Gardiner \\ Department of English and Comparative Literary Studies, University of Warwick, Coventry CV4 7AL, UK; \\ M.Gardiner@warwick.ac.uk
}

Received: 25 March 2019; Accepted: 30 July 2019; Published: 2 September 2019

\begin{abstract}
This article argues that millennial Scottish culture has been animated in large part by a push to overcome a historiographical compulsion built into the modern British state's understanding of nature. This understanding of nature became the foundational principle of government during the Financial Revolution and British unification in the 1690s-1710, then was made the subject of a universal history by the Scottish Enlightenment of the later eighteenth century, and has remained in place to be extended by neoliberalism. The article argues more specifically that the British association of progress with dominion over the world as nature demands a temporal abstraction, or automation, reducing the determinability of the present, and that correspondingly this idea of nature 'softens' conflict in a way that points to weapons carrying perfectly abstracted violence. Nuclear weapons become an inevitable corollary of the nature of British authority. Against this, twenty-first century Scottish cultures, particularly a growing mainstream surrounding independence or stressing national specificity, have noticeably turned against both nuclear weapons and the understanding of nature these weapons protect. These cultures draw from a 1980s moment in which anti-nuclear action came both to be understood as 'national', and to stand in relief to the British liberal firmament. These cultures are 'activist' in the literal sense that they tend to interrupt an assumption of the eternal that stands behind both nuclear terror and its capture of nature as dominion over the world. A dual interruption, nuclear and counter-natural, can be read in pro-independence cultural projects including online projects like Bella Caledonia and National Collective, which might be described as undertaking a thorough 'denaturing'. But if the question of nature as resources for dominion has been a topic for debate in the environmental humanities, little attention has been paid to this specifically British 'worlding' of nature, or to how later constitutional pressures on the UK also mean pressures on this worlding. Andreas Malm's Fossil Capital (2016), for example, a powerful account of the automation of production in the British industrial revolution, might be related to the automation of ideas of progress pressed during the Scottish Enlightenment, and entrenching a dualism of owning subject and nature as object-world that would drive extraction in empire. Finally, this article suggests that this dualism, and the nature holding it in place, have also been a major target of the 'wilderness encounters' that form a large sub-genre in twenty-first century Scottish writing. Such 'denaturing' encounters can be read in writers like Alec Finlay, Linda Cracknell, Thomas A. Clark, and Gerry Loose, often disrupting the subject standing over nature, and sometimes explicitly linking this to a disruption of nuclear realism.
\end{abstract}

Keywords: Scottish literature; Scottish independence; Scottish Enlightenment; Scottish millennial culture; nuclear weapons; nature writing; environmental humanities; Thomas A. Clark; Gerry Loose; Alec Finlay; Zen Buddhism 


\section{1. 'Classical liberalism', the Core of British Empire, Has a Specific Hold on nature}

There is a specificity to the term 'classical liberalism' that is rarely registered. In large part, classical liberalism refers to the ideas establishing and consolidating the modern British state; and the particular ability of classical liberalism to found a coherent 'world' arises from this state's ability to harness a universalist, empiricist conception of human dealings with nature. It is classical liberalism's institutionalisation in the new British state in the late seventeenth century that governmentalises and then globalises an understanding of the seeing-owning subject who stands over nature, or conversely, natures that stand in relation to human subjects as resources. Nature, in the revolutionary cosmology associated with Newton and Locke, depends on a temporal stabilisation: there is a constant dynamic dispersal of resources down towards individual owners, but this dynamism is determined by laws of motion that are fixed and empirically describable. For the 1688 state, eternally and in a way that can never be codified, nature, paradoxically, is the world's progressive conversion to property. However, this thinking of nature only really becomes a global rationale for extraction when it is made the basis of a universal historiography during the Scottish Enlightenment. Numerous thinkers of the Scottish Enlightenment work to 'automate' nature as the progressive conversion of the world to property, describing an inevitable historical movement towards more production. Although there is good reason to suggest that this automation is also the automation standing behind Britain's 'moral' drive to fossil fuels, its 'Britishing' specificity has not been much registered by the environmental humanities, and this is something I want to register here. But to this I also want to add firstly that the progress associated with this nature, since it is based ultimately in a historical abstraction, leads to 'total' weapons, weapons that can't be used, but that maintain discipline precisely through their ability to 'eternalise' conflict-or put otherwise, weapons that hold nature in place. Secondly, as this narrowing of progress under British liberalism runs its course, millennial Scottish culture has on the contrary been marked by a deautomation. And thirdly, this deautomation, the unravelling of an exclusive abstraction of progress, also sets millennial Scottish culture against total weapons. An interruption of the nature that progressively separates owners from object-world is also an interruption of a ban on political determinability supported by nuclear weapons' 'eternalising' force. Nuclear weapons are so culturally fundamental for this reason: they anchor the flattening of time that protects British nature, and their eternal is the eternal of the abstraction of action into an economic relation to an object-world of resources. Much millennial Scottish writing-I will point to cultural-political journalism and 'wilderness writing' - sets itself precisely against such an abstraction. I will come shortly to the striking commonness of opposition to nuclear weapons in 2010s pro-independence cultural movements, then to the related 'denaturing' suggested by some Scottish 'wild walks'. Before these, though, it might be useful to say more about why the foundationally British attitude to nature was time-fixing, why the Scottish adjustment to British Union during the Enlightenment was crucial to this time-fixing, and why nuclear weapons would eventually become its corollary.

It is well known that a commercial-minded individualism was established as the key principle of government during the 1688-1707 period. Less often discussed are the cosmological claims this involves, the new appeal to eternal laws of nature. Late seventeenth-century English thought increasingly placed nature at the heart of government, increasingly understood authority as evolving organically, and increasingly wanted to show this evolution empirically. John Locke's Two Treatises of Government (1689) is perhaps the best-known claim for the status of the individual coming to stand over the world in a relationship of knowledge and ownership, and for seeing the social realm as a product of this relationship to nature (Locke 2010, p. 350). That a 'proprietorial' definition of nature had been building in England for a while was described as long ago as Carolyn Merchant's now-classic The Death of Nature (1980) (Merchant 1980). But the Locke who draws from Newtonian cosmology might be seen as this tradition's crescendo, a rationale for its domestication as statecraft, and a harbinger of how empiricist definitions of nature will play out in commercial empire. The individuation of resources now follows natural laws of motion, and 'natural science' becomes the key descriptor of the progressive dissipation of resources from 'despotic' powers (cf. Mirowski 1989; Kennedy 2015). The defining role of the new 
state would be to protect nature as property from despotic, that is, political, forces; and the natural law it domesticates would become a kind of crypto-metaphysical realism of money ('British values'). Ultimately, Locke recognised, in a stable progressive society money would have to be universally reliable as a medium of exchange, an imperative to sound currency he saw as the real reason for founding the new state (Caffentzis 1989, pp. 53-54). An economic stabilisation of progress as a rise over nature then becomes the definition of the subject relative to a universally reliable currency; and this personal time-fixing, a kind of financial realism, is fundamentally what Britain is.

Crucially however, if the empiricist bones of this time-fixing were set out at the end of the seventeenth century, it would only be given a really globally viable ethics during the Scottish Enlightenment. Scottish adjustment to British Union and Empire accelerated particularly after the unifying moment of the 1740s-50s, driven in large part by an apparent need to affirm empiricist rules of progress that would allow individuals better ('fairer', more measurable) access to an expanding imperial public (cf. Davie 1994; Nairn 1981; Pittock 1997; Pittock 2003). Scottish Enlightenment thinkers tended to agree with Locke that the individuation of property broke down despotic powers, but they further theorised this as a universal process, and one defining the forward movement of history as such. The linking of civilization to dominion over nature in industrial production is well known of Adam Smith's Wealth of Nations (1776), but by this point Smith, like many other Enlightenment literati, had already posited a universal history leading upwards to 'commercial society'; nineteenth-century Scottish liberals in empire would make this ascent into a global aspiration, and the basis of the progressive good of extraction, production, and exchange (a thinking to survive, of course, into the 'extractive' twentieth century) (Smith 1982, pp. 109-26; Smith 1978, pp. 14-37). ${ }^{1}$

In this sense, breaking away from a historiography of nature as the basis of production might be seen, somewhat counter-intuitively, as a positive 'denaturing'. Something like this denaturing has been an ongoing concern of environmental philosophy since the late twentieth century, often concerned with a 'turn against nature', where nature has this sense of a detached object-world conceived in terms of dominion. One version of this turn can be dated from Ross McKibben's description in The End of Nature (1989) of the demise of 'a certain set of human ideas about the world and our place in it', an account of an understanding, growing through environmental crises, of how 'we have ended the thing that has, at least in modern times, defined nature for us-its separation from human society' (McKibben 2003, pp. 7,68$)$. The potential consequences of the fall of nature as the world's relation to seeing-owning individuals have been taken up in various ways by twenty-first century environmental thinkers. In Capitalism in the Web of Life (2015) Jason W. Moore describes 'how the mosaic of relations that we call capitalism work through nature', and sees a growing seventeenth-century-and prior-willingness to ascribe values to an object world (Moore 2015, p. 1). Moore is less interested, though, in origins for the 'worlding' of this nature in the cohering phase of British union and empire. Similar might be said of the Marxian idea, associated with John Bellamy Foster and others, of 'metabolic rift', a scission in the human-nature relationship created by the needs of production - but ultimately traceable back through liberal tradition and the needs of the empiricist self (cf. Foster 2000). The discursive field of the loss of nature as a reliable world is set out by Steven Vogel in Thinking Like a Mall (2015), which describes how a tendency to equate environment with nature gives the latter a backhanded metaphysical binding - though we might see this binding in terms of the needs of the 'secular religion' of Protestant commercialism founding the new British power, then moralised in the Scottish Enlightenment (and indeed illustrated for Vogel by Smith's image of the 'invisible hand') (Vogel 2015, pp. 2-9, 17-23, 67, $75,88)$. Vogel and others understand empiricism's crucial role in maintaining an individual knowing (or owning) self distinct from the world, as well as its promise of representation-a representation unimpeded by 'despotic' politics, or interruptions to economic nature. But when Vogel suggests that

1 A comparable case on extractable nature has been popularised by Moore (2015); on the reliance of extraction on dualism, called 'Cartesian' in Moore, and a possible remaining dualism in Moore's human/ nature, cf. (Wark 2015). 
this conception of nature is easily co-opted to the 'reactionary and oppressive', he risks missing British liberalism's unusual power to trap its citizens in the progressive, to bind the social to a property-driven historical ascent, and to see this binding as the work of nature (Vogel 2015, pp. 26-28, 45-46). From another region of environmental theory, empiricist nature's ability to act as a temporal regulator had already suggested explicitly by Timothy Morton's Ecology Without Nature (2007), describing how the term tends to be 'wheeled out to adjudicate between what is fleeting and what is substantial and permanent. Nature smooths out uneven history' (Morton 2007, p. 21). Nature does indeed smooth out uneven history, but this temporal smoothing has a specific constitutional fix. Nature's economic stabilisation of time is 'worlded' in empire, but its origins are in the foundational needs of the British state; and conversely, depictions of unevenness within the British state will tend to destabilise it, which is what Scottish culture will later increasingly do.

Another way to say some of this is to say that environmental philosophy's critique of nature as an object of dominion has tended to overemphasise Cartesian dualism at the expense of Lockean dualism. It is true that Cartesian dualism, the stated focus of Moore and others, describes the individual's separateness from the world as an object of knowledge. But only in Lockean dualism does ownership become an ethical basis for government, and a government whose basis in nature, as in late seventeenth century English thinking, assumes an exceptionally placeless status. Only Lockean dualism could be 'worlded' into a virtuous historiography founded in resource extraction. Only in Lockean dualism is the body itself properly understood as the property of the rational subject, allowing labour to be legitimately traded, and so, as Smith would affirm, to animate civilization. Something like this is in fact powerfully hinted by Andreas Malm's account of the British industrial revolution in Fossil Capital (2016), a book that is highly specific about the British fix of production as progress, yet tends to miss the role of eighteenth-century British unification (Malm 2016). A compelling labour history as well as an environmental history, Malm's account describes fossil fuels' role in a drive to escape the difficulties of animate labour-workers' instincts, appetites, tendencies to form unions, and so on. But it does not note that a tendency to see labour as already 'objective', as property-producing, has origins in the Lockean-Smithian consolidation. Malm makes much of the way the move from the water wheel was driven by the flexibility and mobility of James Watt's 1784 patent engine, but he does not discuss the way the morality of this drive towards automation had already been established by Enlightenment historiography, for which improvements in production were the ground of progress itself (Malm 2016, pp. 156, 176, 267). For Malm, only in the desire for automation and dominion over nature that passed through the steam engine could 'expansion be called out to live eternally', but this eternal is the core of the British grounding of nature, the Newtonian principles that centre the world on the empiricist self (Malm 2016, pp. 16, 21-22, 65-68, 74, 117-24, 164, 193, 204-6, 257, 296). Only this 'ethical automation' can explain the extraordinary moral push for production in this country-Britain accounted for $80 \%$ of global $\mathrm{CO}_{2}$ emissions in 1825-and the condition in which, as Malm puts it, if 'global warming has a historical homeland, there can indeed be no doubt about its identity' (Malm 2016, pp. 253-54). Similarly, while Morton sees this same historical moment of Watt's 1784 patent as signalling a terminal change in the human-nature relationship ('the end of the world'), he doesn't relate Watt's engine to the automation of history in terms of production, whose moral case had been set out, tremendously influentially, by Smith's Wealth of Nations only eight years before (Morton 2013, p. 7; Malm 2016, p. 53).

All of this suggests that although 'objective nature' is a concern of the environmental humanities, objective nature's rise as the historiography of the British empire is much less so (and so, for that matter, are the British foundations of the automation in whose shadow merely knowing more about carbon emissions does not cause us to reduce them). A binding to this nature suffuses all physical encounters with an anterior set of eternal laws corresponding both to the eternal ground of Locke's subjective adjustment to universal exchange and to Newton's laws of motion. This eternalising role for nature leads to the Whig promise to reduce violence by removing present-tense political determinability, a claim relied on by liberal defences of British government rising through Edmund Burke's iconic case against the French Revolution (Burke 1986). Inevitably, this abstraction of violence, or of the political, 
relies on an ever more complete identification of the present with progressive laws of nature, and so with development itself. And equally inevitably, this temporal abstraction has to continue until all physical determinability disappears under a total temporal discipline. Thus the liberal desire for nuclear weapons, weapons that enforce absolute delay, particularly in the 'non-violent' standoff of Mutually Assured Destruction that accompanied the institutional rise of British neoliberalism. The certainty that progress abstracts violence was implicit in much Scottish Enlightenment historiography, for which commercial society meant the increasing suffusion of relationships by economic mediation, in the sensibility Smith called sympathy—and sometimes this certainty was quite explicit, as in John Millar's description, in Origin of the Distinction of Ranks (1778), of how the movement towards commercial society necessarily brings a softening of war (Millar 2006, pp. 229-35). The softening of war demands the penetration of all human relations by a mediating economic historiography-something now familiar in neoliberalism's need to keep identifying and castigating physical force (especially those associated with some kind of biophysical collectivity, the masculinity of industrial unions for example). This progressive softening would always give Britain a particular binding with, and existential need for, total weapons. ${ }^{2}$

Total weapons then accord with nature not only in the constructionist sense described by Vogel, the extent to which nature is in some sense always made by humans; total weapons also maintain nature as object-world. Especially during the post-1979, Europe-centred, high tension phase of Mutually Assured Destruction, when they reach their full potential, nuclear weapons stabilise the perpetual abstraction of determination. Physically useless, such weapons are non-violent in Burke's sense, but are constantly being used. This is why I have described nuclear weapons' maintenance of an 'undead' continuity, and against this continuity, 1980s Gothic depictions of actual nuclear violence that reinsert embodied time, the deaths that are supposedly unthinkable under the nuclear regime. Within Scottish culture a national tendency to stand apart from the neoliberal firmament has been entangled with the imagining of actual physical violence in the nuclear deterrent; and millennial Scottish culture has been deeply marked by this turn to determinable time, and a corresponding rejection of the nuclear abstraction. This is part of the reason self-determination is after all a useful term for independence, suggesting a contrast to automation, and standing in relief to British nature. Self-determination suggests active time, a time fundamentally at odds with nuclear realism. It means a simultaneous rethinking of nature as the progressive fixing of nature as object-world, and of the static condition of terror that protects it. Disarmament then becomes normal to Scotland in the way nuclear weapons are normal to Britain, suggesting a markedly different cultural orientation in the late twentieth and early twenty-first centuries especially. It is not simply that this makes Scottish culture more 'forward-looking' - it is more fundamentally that it will tend to root Scottish culture more in experiential time.

The realisation that there had never really been a full constitutional acceptance of Britain's 'natural' authority had been an important element of Scottish critique as early as the 1950s. But a new kind of cultural watershed came after 1979, with the combination of the Thatcherite return to the economic understanding of nature and strong money I have described as 'neo-Lockean', and its accompaniment, the new commitment to total weapons, the familiar double disciplining of money and time (Gardiner 2017). A clear vision of nature as sound money was stressed by the F.A. Hayek who worked alongside a battery of home-grown liberal activists at the London School of Economics and the Institute for Economic Affairs in the 1970s, and who described the need to overcome despotic or political threats to civilization through a constant, Newtonian, expansion of the natural rule of economic law (cf. Hayek 1973). Where Malm describes the British investment in the steam engine's creation of apolitical labour, Hayekian nature is just the same-it overcomes politics by affirming the automation of the process by which the world is turned to property (Malm 2016, p. 215). For Thatcherites then, and in a sense against which Scottish culture would significantly cohere and 'nationalise', the flow of money 
again characterises nature, but this nature is now supported by the time-fix of nuclear weapons. There is a nice description of this liberal binding for total weapons in the largely forgotten 1983 Omega Report by the Adam Smith Institute, for which the target of nuclear weapons is political forces 'depriv[ing] individuals of their liberties under the law' (Adam Smith Institute 1983, p. 3). Numerous Conservative and New Labour politicians of the ' 80 s and '90s confirmed that the real intention of the Trident nuclear programme was to protect Britain's natural authority, and even that Trident was a form of currency. For Tony Blair, while Trident defied common sense, it nevertheless avoided a 'downgrading of our status as a nation', something he saw as 'too big a risk' - paradoxically, when talking about accident-prone weapons that could trigger the end of all human life (Murkens et al. 2002, pp. 89, 90; Blair 2010, pp. 635-36; cf. Wings Over Scotland 2014). But if nuclear weapons uphold liberal dominion over the world as nature, they also require an ongoing Scottish allegiance to this nature's historiography, the historiography pressed by the 'Britishing' tendencies of the Scottish Enlightenment. During the standoff following the post-1979 intensification of anxiety (the 'New Cold War'), and again in the nuclear-backed 2010s debates over self-determination, this allegiance is exactly what frays.

This is to suggest, then, that nuclear weapons can be read as a dividing line in millennial cultures. Within the independence debates, this meant a serious interrogation of the existential importance of nuclear weapons to British union-what the House of Commons Defence Committee described in 2013-14 as 'the defence philosophy of the UK' (House of Commons Defence Committee 2014, '3. Nuclear Deterrence'). Indeed nuclear weapons' stabilising role in the economy had been underscored soon before this, when in the midst of the 2008 financial crisis, Trident was renewed as public investment by Alasdair Darling - the figure who would later lead the campaign against independence (Stratton and Seager 2008). In 2012, Defence Secretary Philip Hammond challenged 'the SNP' (meaning those advocating self-determination) to 'fill the economic void' without Trident; and in 2014 Vice Admiral John McAnally warned about post-independence damage to defence as a British brand (MacNab 2012; Graham 2014). Cultures of self-determination can be read largely in terms of their pulling away from this economic-nuclear bind, in the 2010s most pointedly, but in a way that had been coming since 1979, and this might also be seen as part of the rationale of the (sometimes derided) dating of the 'Second Scottish Literary Renaissance', a wave of often nationally-conscious writing from the early 1980s to '90s. As well as tending to draw away from the reduction of progress to property-convertible nature, this long sweep has seen a locally-specific crisis of (UK) parliamentary representation, representation whose form as well as whose content is ultimately economic. This crisis of representation is sometimes broadly known as democratic deficit, and Scottish nuclear scepticism is a key element in it.

\section{Democratic Deficit Is a Crisis of British Nature, but also the Basis of an Active Scottish Culture}

The phrase democratic deficit has typically been understood to describe a double distancing in Scotland in 1979, after the failed devolution referendum and Thatcher's first General Election victory. Democratic deficit could be understood more widely, though, recognising an unevenness in a natural, that is, economic, understanding of representation. Either way, the overcoming of democratic deficit inevitably has a degree of national specificity, and stands in contrast to an assumed universalism defined precisely by its not being limited by the national—-the parameters of today's tortuously-defined 'British values'. Against such a natural firmament, national specificity points up a real constitutional unevenness, recognised especially from the late twentieth century as never having been entirely smoothed by the eighteenth-century adjustment. Recognition of democratic deficit unbalances the representative medium associated with nature (the 'unlimited sovereignty of parliament'), but in doing so it also unbalances any imagined consensus over the forces holding it in place. Building on this recognition of unevenness, I make three related suggestions.

Firstly, readings of early twenty-first century Scottish culture might keep an eye on a longer de-adjustment relative to democratic deficit and the post-'79 Cold War. The cultural-political journals supporting independence in the mid-2010s have much in common with the wave of post-'79 
cultural-political journals that takes in, for example, Cencrastus from 1979, Radical Scotland from 1982, and Variant from 1984 (cf. Easton 1982). In both moments, there is a recognition of actions outwith the representation that has been given the form of nature. Moreover in this context nuclear realism becomes an obvious divider in ideas of representation, as all major Westminster political parties give up on unilateral disarmament, formally during the Neil Kinnock leadership, but in practice from 1983, detaching action understood relative to total violence from representation as such (cf. Welsh 2001, pp. 150-205). An 'activation' of non-(UK)-parliamentary action also helps explain the tone of much 2010s independence campaigning, why it appeared cultural, why it often looked independent, DIY, and precariously funded despite large audiences. National Collective, for example, an association of cultural practitioners that eventually numbered over 4000 activists and described itself as 'the cultural movement for Scottish independence' (National Collective n.d.). Or Bella Caledonia, established in 2007, and following independent magazines like Product, edited by Mike Small, food activist, journalist, and scholar of Scottish environmentalism, and Kevin Williamson, whose Rebel Inc. platformed authors including Laura Hird, Irvine Welsh, and Alan Warner in the '90s, and so a big chunk of the raw material of the Second Scottish Literary Renaissance. Despite the tendency of academic commentary to want to size individuals up for canon entry, the reach of groups like National Collective and Bella Caledonia in the mid-'10s is perhaps the century's biggest Scottish literary-cultural story so far; and around these coalesced a broad groundswell of other smaller cultural-political outlets. For these cultural streams, peripheral yet also oddly mainstream, self-determination falls outside of the progress protected by the temporal totalisation, just as it stands outside of British nature. Cultures of self-determination, in strictly Smithian terms, are not progressive at all-a connotation widely relied on to castigate independence as nationalist, political, unnatural.

Secondly, in pulling away from a historiography based in 'nature', self-determination cultures have been marked by the return of the possibility of action as such. A temporal reorientation towards action is obvious from common references (Bella Caledonia, Better Nation) to the early writing of Alasdair Gray, whose Lanark (1981) had brought a recognition of democratic deficit and of the freezing of determination in nuclear neoliberalism. Behind the broad thematic adaptation of Gray is not simply the idea that independence cultures belong to idealistic young folks, but more seriously a philosophical recalibration towards the determinable, a chipping away at a historiography of nature. Besides the obvious fact that independence campaigners and devolved institutions were more given to green policy-an advocacy seen in Bella Caledonia particularly—readable throughout these journals is a drawing away from the temporal fix of British nature. This denaturalisation amounts to a political 'activation' of everyday life, or a rise in agency over automation-paradoxically, since agency was the promise made by the Scottish Enlightenment's imperative to rational self-interest. If an orientation towards determinable presents in independence cultures seems too obvious to mention, this is worth comparing to anti-independence arguments' tendency to the ahistorical, their tendency to revert to an unhinged retro. John Barrowman's tartan-themed appeal of 2014, for example, used seriously as campaign material by Better Together, and so weirdly detached from any experienced time that it became famous in its own right (Better Together 2014). There is no real equivalent for this orientation towards present action on a UK level; but this makes sense, given the Scoto-British roots of the original historiographical unification.

Thirdly, insofar as they deautomate the link between nature and production, these cultures resist the temporal abstraction that leads to nuclear stasis. Again in contrast to the UK as a whole, twenty-first century Scottish culture is anti-nuclear so commonly that journals like National Collective and Bella Caledonia often take it for granted in a way that would seem extraordinary in virtually any output of the British left. The same had been true of journals like Radical Scotland and Cencrastus, which had perceived a strong link between a non-Westminster politics and anti-nuclear activism. And overlapping with these, works of the Second Scottish Literary Renaissance had sometimes worried over the connection between nuclear authority and the (neoliberal) assumption of individual dominion over nature. Lanark's alienating skin disease, for example, looking like 'unjust nations 
converting themselves to armour', and the narrator of James Kelman's story 'My eldest' (1998) feeling an inexplicable distance from his son on the beach near Faslane (Gray 2002, p. 68; Kelman 1998). This foundation is extended into millennial cultures' general pull from nuclear realism. Indeed in the 2010s an understanding of the way Trident and self-determination were entangled itself became a cultural faultline, especially given the British media's determination to shift the debates back onto the natural ground of the economy (Scottish Campaign for Nuclear Disarmament 2013b).

Despite this shifting of the debate, a scepticism over nuclear realism can be read as the uniting element of cultures of self-determination, and one of independence campaigns' clearest markers of a national cultural specificity. Scots' general nuclear scepticism even becomes something of a spectre for British representation. Scottish CND (Campaign for Nuclear Disarmement), who had campaigned for independence since 2012, and who had insisted that the referendum's force was in re-normalising debate on nuclear weapons, found in a 2013 poll that $60 \%$ of Scots opposed Trident renewal, with only $14 \%$ in favour; a Panelbase survey the same year suggested 76\% against (Parkinson 2014; Eaton 2013; Wings Over Scotland 2013; Greenwell and Teudhope 2012; The Herald 2012; cf. Scottish Campaign for Nuclear Disarmament n.d.; Chalmers 2011). And during the referendum debates, the Scottish interruption of 'natural' nuclear violence, in a strange echo of the adjustment that had happened during the Enlightenment, was seen to have a concrete influence across the whole UK. Unilateral disarmament had already become more or less unthinkable within British parliamentary naturalism, and now the UK government pointedly dodged the question of a substitute site for Faslane/Coulport in rUK (the rest of the UK), meaning that Scottish self-determination was likely the only means of removing weapons of mass destruction from the UK (cf. Chalmers and Walker 2001, pp. 4-5). The difficulty of relocation was confirmed by Defence Implications of Possible Scottish Independence Sixth Report of Session 2013-14, linking self-determination to the British existential question about nuclear weapons (House of Commons Defence Committee 2013, para 108; Scottish Campaign for Nuclear Disarmament 2014; Sunday Herald 2013). When the Scottish Government's draft Independence Bill clearly committed to eject Trident, former Prime Minister John Major confirmed that independence would 'in effect, be the end of the serious British nuclear deterrent' (Scottish Campaign for Nuclear Disarmament n.d.; Scottish Government 2014; cf. Ainslie 2012; Scottish Government 2013, pp. 14-15; Scottish Campaign for Nuclear Disarmament 2012; BBC 2014). ${ }^{3}$ So as John Ainslie put it, 'Scottish independence would be the "'nightmare scenario" to be avoided at all costs' (Ainslie 2012, p. 4). Pro-independence cultures like those surrounding Bella Caledonia and National Collective now concretised such a nightmare scenario.

Often these nuclear stakes were assumed by the projects like National Collective and Bella Caledonia in a way that is itself telling, but sometimes they were stated outright. In National Collective in 2012, Will Walker rehearsed the difficulties of moving Trident, as well as the non-proliferation issues involved if rUK tried to impose nuclear weapons on an independent Scotland, and concluded that '[e]victing Trident from Scotland therefore amounts to closing down the UK nuclear deterrent' (Walker 2012). Stephen Griffiths's 'The Elephant in the Room' (2014), in Bella Caledonia's indy ideas series, suggested that the referendum had reactivated arguments over nuclear terror that had otherwise, frozen into British stasis, 'begun to take on something of the air of a lost cause' (Griffiths 2014). Bella also linked to this cultural stream organisations like the Scrap Trident coalition, a 'broad-based coalition of groups [that] came together in 2013' and 'worked to keep Trident high on the agenda' of the referendum (Griffiths 2014; cf. Moodie 2012). If the strangeness of such cultural organs' assumptions of an anti-nuclear attitude is easy to forget, this might be laid next to the almost complete absence of pro-nuclear arguments anywhere near the mid-2010s Scottish cultural realm. It is difficult to find any pro-nuclear weapons tendencies in literary-cultural publications at all, though such arguments must have been assumed on some deep realist level—that Scotland's management of nuclear weapons is

3 Moreover the resulting British disarmament 'would be widely welcomed, not just across this country but by most governments around the world'-'An independent Scotland will Ban the Bomb' (Scottish Campaign for Nuclear Disarmament 2013a). 
important, for example, that there is a real threat being answered by Trident, that Scotland should have a say over future generations of weapons, or even that Trident is a national good because it creates jobs. ${ }^{4}$ This last Lockean appeal to labour-based citizenship (in fact a classic claim going back decades) was more or less debunked during the mid-'10s 'pamphlet war': where a warning on the 'Defence Implications of Possible Scottish Independence' suggested the loss of 1700 jobs, pro-self-determination writers pointed out that in fact these (1200-)1700 jobs were so heavily subsidised that even on conservative estimates it would make more sense to pay Trident workers ten times their current wage not to work at all-in other words, the 'work' of Trident is really in its ability to perform a timeless authority, to stand for nature as such (Scottish Campaign for Nuclear Disarmament n.d.; cf. Wings Over Scotland 2014, p. 34).

A question behind these cultural battles, I have been suggesting, is of self-determination as interruption of the timeless rise of the owning subject over the world understood as nature. The resulting cultures may or may not be 'nationalist', but it is not surprising that they peel away from an understanding of the social realm that makes a virtue of this nature. And for the same reasons it is not surprising that they peel away from the nuclear abstraction that derives from this 'static' view of progress. To maintain a nuclear deterrent in an independent Scotland would be to assume that there had been no dent in the Enlightenment's 'commercial society' assumption of nature as object-world (or perhaps in 'cheap nature', as Moore puts it). Scottish cultures of the last half-century, though, are deeply marked by such dents. There is certainly a Scottish Enlightenment origin to the 'softening' of war into a perpetual non-physical abstraction; but, I have suggested, this 'Britishing' process has been subject to a cultural unpicking, especially since the awareness of democratic deficit, in a double rejection of 'nature' and nuclear terror, which is really a double registration of the same historiographical interruption. Moreover, and beyond the obvious points that there are more opportunities for green policy on a Scottish than an (r)UK level and that Scotland has much of the UK's 'wild' space, this interruption says much about an unusually extensive body of twenty-first century 'environmental', 'wilderness', or peripatetic writing. Much of this writing is overtly sceptical about the inexorable rise of the subject over nature, and sometimes sets its concerns against an explicitly nuclear backdrop.

\section{Dropping Nature Means Dropping the Totalising Dominion of Subjectivity, and Dropping Total Weapons}

The question of total weapons in twenty-first century Scotland, then, is not only a question of policy, nor even only a question of 'attitudes'; it is also the basis of a cultural contest over nature as economically-denominated progress. I have suggested that British liberalism's commitment to the production of economic subjects relied on an 'automating' historiography, a historiography whose promise of individual sovereignty locked populations in to an extractive relationship to the world. It might even be said that Malm's use of examples of the British pioneering of extraction to show this extraction's deliberateness might be open to a quite specific misinterpretation, since this drive might be understood in something like the opposite terms-as unwilled, depending on the expulsion of action from the present, in a way that would chime with a Whig tradition of commentary on Britain's 'organic' constitution (and the kernel of truth in the statement, associated with J.R. Seeley, that the empire was acquired 'in a fit of absence of mind') (Seeley 1883, p. 8). Cultures of self-determination, on the contrary, might be described as conscious but counter-subjective; and this is what is found in the disproportionately large seam of twenty-first century Scottish writing on wilderness, sometimes described as 'nature writing', though nature as dominion is typically what it seeks to overcome. If cultural-political journals like National Collective and Bella Caledonia suggest an interruption of extractible nature-a nature understood via the ethical 'automation' which makes it coalesce around

4 Though Better Together's March 2013 pro-Trident briefing curtly describes nuclear weapons as 'the ultimate guarantee of our national security' - 'The UK's nuclear deterrent and the referendum' (Better Together 2013). 
the seeing-owning subject-a large Scottish body of wild walks corroborates an undoing of the subject this automation demands.

Many such wild walks' encounters with the world read like a temporal refusal. Some interrupt the streamlining or automation of time by using anachronism, recovering lost pasts, even verging on the archaeological or the 'hauntological'. One version of this has become associated with Robert Macfarlane, who depicts walks across the Cairngorms in The Old Ways (2012)—though a comparable 'environmentalising' of the subjective flattening of nature might be found in earlier Scottish writing including Jim Crumley's A High and Lonely Place (2000), or Hamish Fulton's Wild Life: walks in the Cairngorms (2000) (Macfarlane 2013; Crumley 2000; Fulton 2000; Manfredi, n.p.). Some walks pointedly refuse to see their poetic language in terms of the promise of representation that Enlightenment thinkers had associated with the progressive ascent to commercial society, instead embedding words in specific places to act as things in their own right-the environmental word-sculptures common, for example, to Fulton and Ian Hamilton Finlay before him, and with one origin in the 1960s concrete poetry which itself had a major base in Scotland. Some mountain writing stresses an encounter with geological, that is, non-subjective, time, echoing a tendency of First (1920s to 1930s) Scottish Literary Renaissance writers including Hugh MacDiarmid and Nan Shepherd, then later put into a New Cold War context by Edwin Morgan's Sonnets From Scotland (1984)—and in turn suggesting geological time as national narrative as taken up by a refurbished Museum of Scotland (Morgan 1984, p. 9; Cohen 2015, pp. 189-90; Gardiner and Stones 2018). Less familiarly, Fulton's own walk-pieces from the Cairngorms in 1986 describe stones as 'alive in their homeland', a theme to continue in his later illustration/travelogue/environmental book Human Time/Mountain Time (2010) (Manfredi, n.p.; Fulton 2010). Fulton's environmental work often explicitly thematises a refusal of nature as inert stuff, and raises 'experience over objects', which is to say, over an automated 'worlding' of nature (cf. Manfredi, n.p.). This 'geological' attenuation of subjects' dominion as progress had been a concern of '80s Nuclear Gothic, perhaps most iconically described in the Scottish screenwriter Troy Kennedy Martin's 1985 drama Edge of Darkness, in which the ghost of an activist daughter leads a detective to consider the link between nuclear entrepreneurialism and human extinction, and to a Frankenstein-like journey to a wilderness sublime in the Highlands, where he fades into a mountain (Ferguson 1984, p. 8; cf. Gardiner and Stones 2018). ${ }^{5}$ Traces of the post-nature sublime in Edge of Darkness's stage of nuclear standoff and democratic deficit echo through to the twenty-first century Scottish wilderness encounters, in fiction as well as travelogue. Jenni Fagan's The Sunlight Pilgrims (2016), for example, like Edge of Darkness, stages a Highland encounter with geological time and human extinction, and an interest in post-human fauna, and sees the subjectivity-eclipsing floes of the coming ice age as 'utterly strange and perfect' (and sees the people passing from the earth as 'made of carbon and light', in an uncanny crystallisation of my terms above, describing the 'fossil Enlightenment') (Fagan 2016, pp. 206, $234,293,305)$.

One introduction to these themes in wild walking, or wild habitation, as well as to their rejection of subject-centred nature, is the collection A Wider Vein (2009), edited by Linda Cracknell. This begins with an account of the lonely inhabitation of the Ardnamurchan area by Gerry Loose, an inhabitation aware of the built environment but concerned with animal and geological times, and cultivating what Loose in An Oakwoods Almanac (2015) would call, in a pointed historiographical rejection of British nature, an 'exuberant purposelessness' (Loose 2009; 2015, pp. 91, 94; cf. Cracknell 2014). In the same collection, Mandy Haggith helpfully frames the question of wildness: whether or not Scotland really has wild places, wildness can be understood as a stance towards the world, and 'a place [can] regain wild character ... [just as] a person can move counter to the mainstream urban currents of consumer culture' (Haggith 2009, p. 76). These 'urban currents' are also the currents described by Malm as the

5 The first script of Edge of Darkness, as is perhaps now well known, has Craven becoming a 'green man', a person entangled with the wild, rather than a mountain. Edge of Darkness has also been talked about interestingly and convincingly within a framework of Scottish cultural history by Riach (2005, pp. 205-25). 
specifically British patterns of labour migration following productive automation, the progressive urban individualism of the industrial worker-they are a product of a specific understanding of nature. And the wild is not nature's countryside, but rather a place beyond the discipline of the progressive of property-creation (Locke) or efficient production (Smith). The wild is not historiographically or productively automated, and in this sense is where Scotland comes to terms with the legacy of its own Enlightenment adjustment to British union. Its counter-subjectivity is like that long readable in the poetry of Thomas A. Clark, whose minimalism often tends towards the concrete, and who often narrates the environmental disappearance of the viewer-owner, and indeed hints at possible movements of time that don't simply collapse into the progress that arranges the world of the empiricist self-the time, for example, of 'the prevailing wind' (Clark 2013, n.p.). Clark's The High Path (2003) seeks amongst grasses for 'the manifold/spaces little places/where intention is/no longer gathered' (Clark 2013, n.p.). And in his The Hundred Thousand Places (2009), a walker lets the path determine the walk, sloughing off subjectivity on the way (Clark 2009, p. 74). In such non-subjective places, non-automated lives become possible, and environment stands in relief to the nuclear abstraction.

Indeed the connection between nuclear weapons and the nature that houses nuclear weapons has been indicated quite explicitly by Loose, specifically when he locates an encounter with wildness in the area around Faslane. In Loose's 2014 sequence Fault Line, nature as objective picturesque is repeatedly interrupted by an awareness of the nuclear base. In a way that ties together the nuclear sublime and the wilderness text, nature is made to face the spectre of actual violence it otherwise elides. The encounter echoes the interruptive violence of Nuclear Gothic, and Loose's own 1980s work on the American nuclear presence and cold war paranoia, and subjects the unspoken presence of total weapons to a denaturing - so for example, 'the white hind has/scented me/ ... she follows my gaze/over her shoulder/to hillside bunkers' (Loose 2007, pp. 53-69; 2014, p. 5). ${ }^{6}$ As with many wilderness texts, the counter-pastoral is also a countering of the nature underwired by the nuclear presence.

Unsurprisingly, this kind of denaturing in twenty-first century Scottish writing is often, not least in Clark and Loose, seen as having something in common with the overcoming of the dominion of the subject in Buddhism. Fulton's description, for example, of a commitment to 'the impermanence of self, or "self as process"'; or the relation of 'conscious, counter-subjective' walking with the practice of walking meditation, or kinhin (Manfredi, n.p.). ${ }^{7}$ There are frequent Zen Buddhist gestures in Loose's An Oakwoods Almanac, which suggest, as Camille Manfredi puts it, an 'engagement with the minutest details of the living and non-living worlds', and similar gestures in Alec Finlay and Ken Cockburn's the road north (2014), which re-sites Matsuo Bashō's early Edo journey from the capital to the provinces to a route from Edinburgh to the Highlands (Manfredi, n.p.; Manson 2007, p. 7; Cockburn and Finlay 2014). More widely, Buddhist themes are taken up in the early twenty-first century by, amongst others, John Burnside and Alan Spence, and references to Matsuo specifically reach as far into the curricular mainstream as Kathleen Jamie's Sightlines (2012) (Burnside 2012, p. 39; Spence 2006; Jamie 2012; cf. Gairn 2008, p. 186; Manfredi, n.p.). ${ }^{8}$ Precedent lines of Zen moreover reach back into the twentieth century, via Neil M. Gunn's own wild places, and via Kenneth White and the 'geopoetic' environmental writing to follow (along with gestures towards the geological that, as Manfredi describes, recall MacDiarmid's 'On a Raised Beach') (Gairn 2008, pp. 133-35; cf. Gunn 1956, pp. 75-81, 134-40; Burns 1998; Manfredi, n.p.).

Zen then could plausibly be described as a central theme of twenty-first century Scottish writing. This is presumably taken by some commentators to connote a kind of passivity, but Zen, along with a revived neo-Confucianism, had been the impetus behind a powerful mid-twentieth century Japanese

6 Elsewhere I have described how imagery of the lochs and glens around Faslane in '80s nuclear documentaries linked nuclear fear and Scottish independence, and similar is readable in Dick Gaughan's 'As I walked on the road', used by Duncan Campbell in his Secret Society documentary In Time of Crisis, BBC, 2007.

7 Kinhin is the Japanese term, and is not being quoted from these texts.

8 And 'one of the very best things about the world is that so little of it is me' (Greig 2009, p. 218). 
attempt to overcome the universalism still ascendant in the 'wordling' of the British empire, and in particular the Anglosphere assumption that subjectivity was the primary structuring principle of all social organisation. Julia Adeney Thomas has described an intense contest over the term nature (shizen) in Meiji Japan, and here I have suggested similar of the nature leading to the authority basis of the early British state (Thomas 2002). But the British conception of nature as the arrangement of the world around the seeing-owning subject was precisely what was critiqued by the thinking sometimes called 'Zen nationalism'. Numerous writers of the mid-period (1920s-1930s) Kyoto School, a Buddhist-Confucian engagement with European philosophy with much in common with the localism of the Scottish First Literary Renaissance, describes a politics in which actor and world had not been disentangled, and an important precedent for both environmentalists and wild-walkers-though the bracketing of the Anglosphere progressive this demanded has also tended to get it overlooked as postcolonial critique (cf. Williams 2014; Watanabe 2019; McKibben 2003, p. 69). The point of this is not just that the Zen echoed by writers like Clark, Loose and Finlay already had a long history of conflict with British historiographical universalism, though this is important in itself-but also that Zen's threat to the 'worlded' British-liberal subject can be linked to the Anglosphere's redisciplining of Japan using nuclear weapons. As well as their immediate and strategic military purposes, the unprecedented totality of the 1945 bombings, their command over space and time, their dwarfing of locality, effectively eviscerated 'nationalist' ecological entanglements with the world, clearing the ground for new claims to liberal nature in the Anglosphere (and the ground of what would become neoliberalism) (cf. Lippit 2005). This, broadly, is what nuclear weapons continue to do. And this is why 'Zen walking' in twenty-first century Scotland finds itself in a standoff with British abstracted violence. Nuclear weapons counter threats to nature understood as the centring of the world on an owning subject. This also helps explain why the re-strengthened mandate for universalism in 1945 sees the nuclear deterrent, paradoxically at first glance, become a crucial element of the British welfare state-Nye Bevan's famous comment call for the bomb with 'a union jack on it' (e.g., Hennessy 2007, p. 48). Bound up in the Zen of Scottish wilderness, then, as it is in the historiographical disobedience of pro-self-determination journals, is a challenge both to a realism of nature as not only empiricist (Descartes) but also economic (Descartes plus Locke), and to the total weapons that form the ontological spine of this understanding of nature.

Millennial Scottish wilderness writing, then, might be read in terms of a desire to overcome both objective nature and the nuclear 'freezing' of action. There are doubtless many more links that could be made between twenty-first century Scottish writing and the localising aesthetics of the First Scottish Renaissance (and of the Kyoto School, for that matter), but here I have tried to stress the importance of property-convertible nature, its basis in the fixed progressive, and its corollary of total weapons. ${ }^{9}$ Total weapons are such a cultural shibboleth because they protect against the deautomation of progress, against interruptions of nature, interruptions of an extractive vision of the world, and interruptions of nuclear realism. Nuclear weapons keep nature in its place. It is not surprising that Scottish culture is so concerned with the question of the stability of this idea of nature, since the stabilisation largely has its roots in the Scottish adjustment to British universalism. But nor is it surprising that millennial Scottish culture should lean so heavily towards its overcoming.

Funding: This research received no external funding.

Acknowledgments: I acknowledge the help of Jack Colvin in the nuclear-related research for this essay.

Conflicts of Interest: The author declares no conflict of interest.

9 Though cf. Robert Crawford's argument on a Scottish millennial ecological turn referencing the First Scottish Literary Renaissance, and centred on Kathleen Jamie, John Burnside, and himself-Scotland's Books: The Penguin History of Scottish Literature (Crawford 2007, p. 563). 


\section{References}

Adam Smith Institute. 1983. The Omega File—Defence Policy. London: Adam Smith Institute.

Ainslie, John. 2012. Trident: No Place to Go.. London: Campaign for Nuclear Disarmament and Scottish Campaign for Nuclear Disarmament, Available online: http://www.banthebomb.org/images/stories/pdfs/ noplacefortrident.pdf (accessed on 8 March 2019).

BBC. 2014. John Major on BBC Today Programme. June 18. Available online: https://www.bbc.co.uk/programmes/ b046168y (accessed on 8 March 2019).

Better Together. 2013. The UK's Nuclear Deterrent and the Referendum. Available online: https://b.3cdn.net/ better/1d626f971129f12f3e_71m6baqxn.pdf (accessed on 8 March 2019).

Better Together. 2014. John Barrowman's Burns Night Immortal Memory. Available online: https://www.youtube. com/watch?v=sArFksxhV-0 (accessed on 8 March 2019).

Blair, Tony. 2010. A Journey. London: Hutchinson.

Burke, Edmund. 1986. Reflections on the Revolution in France. London: Penguin. First published 1790.

Burns, John. 1998. Celebration of the Light: Zen in the Novels of Neil M. Gunn. Edinburgh: Canongate.

Burnside, John. 2012. The Light Trap. London: Jonathan Cape.

Caffentzis, Constantine George. 1989. Clipped Coins: Abused Words and Civil Government, John Locke's Philosophy of Money. New York: Autonomedia.

Chalmers, Malcolm. 2011. The United Kingdom: A Status Quo Nuclear Power? In Small Nuclear Forces, Five Perspectives. Edited by Malcolm Chalmers, Andrew Somerville and Andrea Berger Chalmers. London: Royal United Services Institute for Defence and Security Studies, pp. 13-26.

Chalmers, Malcolm, and William Walker. 2001. The UK, Nuclear Weapons and the Scottish Question. East Linton: Tuckwell Press.

Clark, Thomas A. 2009. The Hundred Thousand Places. Manchester: Carcanet.

Clark, Thomas A. 2013. The High Path. Nailsworth: Moschatel.

Cockburn, Ken, and Alec Finlay. 2014. The Road North. Bristol: Shearsman.

Cohen, Jeffrey Jerome. 2015. Stone: An Ecology of the Inhuman. Minneapolis: University of Minnesota Press.

Cracknell, Linda. 2014. Doubling Back: Ten Paths Trodden in Memory. Glasgow: Freight.

Crawford, Robert. 2007. Scotland's Books: The Penguin History of Scottish Literature. London: Penguin.

Crumley, Jim. 2000. A High and Lonely Place: Sanctuary and Plight of the Cairngorms. Dunbeath: Whittles.

Davie, G. E. 1994. Hume, Reid, and the Passion for Ideas. In A Passion for Ideas: Essays on the Scottish Enlightenment, Vol. 2.. Edinburgh: Polygon, pp. 1-19. First published 1967.

Easton, Norman. 1982. Marxists for Self-Government. Radical Scotland 2: 16-19.

Eaton, George. 2013. Is the Scottish public really opposed to nuclear weapons? New Statesman. May 10. Available online: http://www.newstatesman.com/politics/2013/05/scottish-public-really-opposed-nuclear-weapons (accessed on 8 March 2019).

Fagan, Jenni. 2016. The Sunlight Pilgrims. London: Windmill.

Ferguson, Frances. 1984. The Nuclear Sublime. Diacritics 14: 4-10. [CrossRef]

Foster, John Bellamy. 2000. Marx's Ecology: Materialism and Nature. New York: Monthly Review Press.

Fulton, Hamish. 2000. Wild Life: Walks in the Cairngorms. Edinburgh: Polygon.

Fulton, Hamish. 2010. Human Time/ Mountain Time. Milan: Charta.

Gairn, Louisa. 2008. Ecology and Modern Scottish Literature. Edinburgh: Edinburgh University Press.

Gardiner, Michael. 2017. Eco-catastrophe, arithmetic patriotism, and the Thatcherite promise of Nature. New Formations 93: 64-79. [CrossRef]

Gardiner, Michael, and Andrew Stones. 2018. Lithic Agency, Scottish Modernism, and the Politics of Nuclear War. Textual Practice. [CrossRef]

Graham, Georgia. 2014. Scottish "yes" vote will force Britain to abandon nuclear weapons. The Telegraph. March 18. Available online: http://www.telegraph.co.uk/news/uknews/scottish-independence/10701826/Scottishyes-vote-will-force-Britain-to-abandon-nuclear-weapons.html (accessed on 8 March 2019).

Gray, Alasdair. 2002. Lanark: A Life in Four Books. Edinburgh: Canongate. First published 1979.

Greenwell, Michael, and Veronika Teudhope. 2012. The Scottish Independence Podcast Episode 14. December 5. Available online: https://michaelgreenwell.wordpress.com/2012/12/05/the-scottish-independence-podcastepisode-14-veronika-teudhope-from-scottish-cnd/ (accessed on 8 March 2019). 
Greig, Andrew. 2009. A Dub in Assynt. In A Wilder Vein. Edited by Linda Cracknell. Ullapool: Two Ravens, pp. 218-20.

Griffiths, Stephen. 2014. The Elephant in the Room. Bella Caledonia. November 2. Available online: https: //bellacaledonia.org.uk/2014/11/02/the-elephant-in-the-room/ (accessed on 8 March 2019).

Gunn, Neil M. 1956. The Atom of Delight. London: Faber and Faber.

Haggith, Mandy. 2009. Wild Life on Braighlinne. In A Wilder Vein. Edited by Linda Cracknell. pp. 70-86.

Hayek, F. A. 1973. Economic Freedom and Representative Government. London: Institute of Economic Affairs.

Hennessy, Peter. 2007. Cabinets and the Bomb. Oxford: Oxford University Press.

House of Commons Defence Committee. 2013. The Defence Implications of Possible Scottish Independence. Sixth Report of Session 2012-13 Volume I. London: The Stationery Office Limited, Available online: https: //publications.parliament.uk/pa/cm201314/cmselect/cmdfence/198/198.pdf (accessed on 8 March 2019).

House of Commons Defence Committee. 2014. Deterrence in the Twenty-First Century. Eleventh Report of Session 2013-14, Volume 1. London: The Stationery Office Limited.

Jamie, Kathleen. 2012. Sightlines. London: Sort Of.

Kelman, James. 1998. My eldest. In The Good Times. London: Secker and Warburg, pp. 47-50.

Kennedy, Gavin. 2015. Adam Smith's Use of the 'Gravitation' Metaphor. Economic Thought 4: 67-79.

Lippit, Akira Mizuta. 2005. Atomic Light (Shadow Optics). Minneapolis: University of Minnesota Press.

Locke, John. 2010. Two Treatises of Government. Cambridge: Cambridge University Press. First published 1689.

Loose, Gerry. 2007. Printed on Water. Exeter: Shearsman.

Loose, Gerry. 2009. Ardnamurchan Almanac. In A Wilder Vein. Edited by Linda Cracknell. Ullapool: Two Ravens, pp. 3-26.

Loose, Gerry. 2014. Fault Line. Glasgow: Vagabond Voices.

Loose, Gerry. 2015. An Oakwoods Almanac. Bristol: Shearsman.

Macfarlane, Robert. 2013. The Old Ways: A Journey on Foot. London: Penguin. First published 2012.

MacNab, Scott. 2012. Philip Hammond lays down gauntlet to SNP over Trident. The Scotsman. October 29. Available online: http://www.scotsman.com/news/philip-hammond-lays-down-gauntlet-to-snp-overtrident-1-2603352 (accessed on 8 March 2019).

Malm, Andreas. 2016. Fossil Captial. London: Verso.

Manfredi, Camille. Forthcoming. Poetics of Space in Early Twenty-First Century Scotland. Basingstoke: Palgrave.

Manson, Peter. 2007. Introduction. In Printed on Water. Exeter: Shearsman, pp. 7-8.

McKibben, Ross. 2003. The End of Nature: Humanity, Climate Change and the Natural World. London: Bloomsbury. First published 1989.

Merchant, Carolyn. 1980. The Death of Nature: Women, Ecology, and the Scientific Revolution. San Francisco: Harper. Millar, John. 2006. The Origin of the Distinction of Ranks: Or, An Inquiry into the Circumstances Which Give Rise to Influence and Authority, in the Different Members of Society. Indianapolis: Liberty Fund. First published 1778.

Mirowski, Philip. 1989. More Heat than Light: Economics as Social Physics, Physics as Nature's Economics. Cambridge: Cambridge University Press.

Moodie, Greg. 2012. 6 Things More Useful than Trident. National Collective. November 3. Available online: http://www.nationalcollective.com/2012/11/03/6-things-more-useful-than-trident/ (accessed on 8 March 2019).

Moore, Jason. 2015. Capitalism in the Web of Life: Ecology and the Accumulation of Capital. London: Verso.

Morgan, Edwin. 1984. Slate. In Sonnets from Scotland. Glasgow: Mariscat.

Morton, Timothy. 2007. Ecology without Nature: Rethinking Environmental Aesthetics. Cambridge: Harvard University Press.

Morton, Timothy. 2013. Hyperobjects: Philosophy and Ecology after the End of the World. Minneapolis: University of Minnesota Press.

Murkens, Jo Eric, Peter Jones, and Michael Keating, eds. 2002. Scottish Independence: A Practical Guide. Edinburgh: Edinburgh University Press.

Nairn, Tom. 1981. The Break-Up of Britain: Crisis and Neo-Nationalism. London: Verso, pp. 19-33. First published 1977.

National Collective. n.d. About Us. Available online: http://www/nationalcollective.com/category/magazine (accessed on 8 March 2019).

Negri, Toni, and Félix Guattari. 1990. Communists Like Us. New York: Semiotext(e). 
Parkinson, Stuart. 2014. Will nuclear weapons be the deciding factor in the Scottish referendum? Scientists for Global Responsibility. September 11. Available online: http://www.sgr.org.uk/resources/will-nuclear-weaponsbe-deciding-factor-scottish-referendum (accessed on 8 March 2019).

Pittock, Murray. 1997. Inventing and Resisting Britain: Cultural Identities in Britain and Ireland, 1685-1789. Basingstoke: Palgrave.

Pittock, Murray G. H. 2003. Historiography. In The Cambridge Companion to the Scottish Enlightenment. Edited by Alexander Broadie. Cambridge: Cambridge University Press, pp. 258-79.

Riach, Alan. 2005. Representing Scotland in Literature, Popular Culture and Iconography. Basingstoke: Palgrave.

Scottish Campaign for Nuclear Disarmament. 2012. Trident Unacceptable in an independent Scotland. January. Available online: http://www.banthebomb.org/index.php/news/trident/1362-trident-unacceptable-in-anindependent-scotland (accessed on 8 March 2019).

Scottish Campaign for Nuclear Disarmament. 2013a. An independent Scotland will Ban the Bomb. November 23. Available online: http://www.banthebomb.org/index.php/102-uncategorised/1500-an-independent-scotlandwill-ban-the-bomb (accessed on 8 March 2019).

Scottish Campaign for Nuclear Disarmament. 2013b. Poll on Trident and Scottish Independence. March 13. Available online: http://www.banthebomb.org/index.php/news/trident/1425-poll-on-trident-and-scottishindependence (accessed on 8 March 2019).

Scottish Campaign for Nuclear Disarmament. 2014. Our Vote Can Influence far beyond Our Shores. August 23. Available online: http://www.banthebomb.org/index.php/news/trident/1591-our-vote-can-influence-farbeyond-our-shores (accessed on 8 March 2019).

Scottish Campaign for Nuclear Disarmament. n.d.a. Vote YES and Ban the Bomb. Available online: https: //www.banthebomb.org/images/stories/pdfs/voteyesbansm.pdf (accessed on 8 March 2019).

Scottish Campaign for Nuclear Disarmament. n.d.b. Draft Bill Shows Yes Vote Will Eject Trident. Available online: http://www.banthebomb.org/index.php/news/trident/1568-draft-bill-shows-yes-vote-will-ejecttrident (accessed on 8 March 2019).

Scottish Campaign for Nuclear Disarmament. n.d.c. Trident and Scottish Independence. Available online: http://www.banthebomb.org/images/stories/pdfs/TridentandIndependence.pdf (accessed on 8 March 2019).

Scottish Government. 2013. Scotland's Future: Your Guide to an Independent Scotland; Edinburgh: Scottish Government. Available online: http://www.scotland.gov.uk/resource/0043/00439021.pdf (accessed on 8 March 2019).

Scottish Government. 2014. The Scottish Independence Bill: A Consultation on an Interim Constitution for Scotland; Edinburgh: Scottish Government. Available online: https://www2.gov.scot/Resource/0045/00452762.pdf (accessed on 8 March 2019).

Seeley, J. R. 1883. The Expansion of England. London: Macmillan.

Smith, Adam. 1978. Lectures on Jurisprudence. Oxford: Clarendon. First published 1763.

Smith, Adam. 1982. The Wealth of Nations Vols I-III. London: Penguin. First published 1776.

Spence, Alan. 2006. The Pure Land. Edinburgh: Canongate.

Stratton, Allegra, and Ashley Seager. 2008. Darling invokes Keynes as he eases spending rules to fight recession. The Guardian. October 20. Available online: http://www.theguardian.com/politics/2008/oct/20/economyrecession-treasury-energy-housing (accessed on 8 March 2019).

Sunday Herald. 2013. UK Government Refuses to Consider Fate of Trident after Independence. November 24. Available online: https://www.robedwards.com/2013/11/uk-government-refuses-to-consider-fate-of-tridentafter-independence.html (accessed on 8 March 2019).

The Herald. 2012. Scots CND Backs Yes Campaign. November 19. Available online: http://www.heraldscotland. com/politics/referendum-news/scots-cnd-backs-yes-campaign.19448929 (accessed on 8 March 2019).

Thomas, Julia Adeney. 2002. Reconfiguring Modernity: Concepts of Nature in Japanese Political Ideology. Berkeley: University of California Press.

Vogel, Steven. 2015. Thinking Like a Mall: Environmental Philosophy After the End of Nature. Cambridge: MIT Press.

Walker, Will. 2012. Scotland against the Bomb. National Collective. June 8. Available online: http://www. nationalcollective.com/2012/06/13/scotland-against-the-bomb/ (accessed on 8 March 2019).

Wark, Mackenzie. 2015. The Capitalocene. Public Seminar. October 15. Available online: http://www.publicseminar. org/2015/10/the-capitalocene/ (accessed on 8 March 2019).

Watanabe, Atsuko. 2019. Japanese Geopolitics and the Western Imagination. Basingstoke: Palgrave Macmillan. 
Welsh, Ian. 2001. Anti-Nuclear Movements: Failed Protests or Heralds of a Direct Action Milieu? Cardiff: Cardiff University School of Social Sciences.

Williams, David. 2014. The Philosophy of Japanese Wartime Resistance. New York: Routledge.

Wings Over Scotland. 2013. Panelbase survey. Wings Over Scotland. October 24. Available online: http://whatscotlandthinks.org/questions/broadly-speaking-what-are-your-views-on-the-uk-havingnuclear-weapons (accessed on 8 March 2019).

Wings Over Scotland. 2014. Wee Blue Book. Available online: https://wingsoverscotland.com/weebluebook/ (accessed on 8 March 2019).

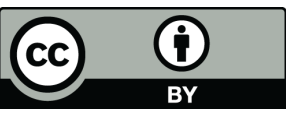

(C) 2019 by the author. Licensee MDPI, Basel, Switzerland. This article is an open access article distributed under the terms and conditions of the Creative Commons Attribution (CC BY) license (http://creativecommons.org/licenses/by/4.0/). 